\title{
Pengembangan Multimedia Pembelajaran Berbasis Lash Animation With Swish Max Siswa Kelas XI SMA Negeri 8 Kota Jambi
}

\author{
Harbeng Masni ${ }^{1}$, Zuhri Saputra Hutabarat ${ }^{2}$ \\ Program Studi Pendidikan Bahasa dan Sastra Indonesia FKIP UNBARI ${ }^{1}$ \\ Program Studi Pendidikan Ekonomi FKIP UNBARI ${ }^{2}$ \\ email: harbengmasni@gmail.com ${ }^{l}$ \\ email: zuhri.saputra.hutabarat@gmail.com²
}

\begin{abstract}
There are several factors that influence learning, including teacher factors, student factors, facilities, tools and media, and the environment. Educators should pay attention to factors that influence learning. The task of the teacher in the learning process, in addition to conveying information, also diagnoses learning difficulties students select teaching materials, supervise learning activities, stimulate student learning activities, provide learning guidance using media, strategies, and methods. Teachers and students are required to master the science and information technology of communication continuously. Teachers need to keep abreast of the development of communication information and science so that they can deliver the latest learning material that is useful for the lives of students in the present and future. The thing that stands out in Swishmax is that the work can be exported into the SWF file format, which is the file format used by Macromedia Flash. Therefore, swishmax animations can be played on any personal computer that has a flash player installed. Swishmax animations can be inserted into web pages, or imported into macromedia flash documents or even in Microsoft Power Point documents. When compared to adobe flash, Swishmax is easier to learn and use for beginners, because the tools available are more user friendly. From the description above it can be concluded that Swishmax is not only multimedia software that is only capable of creating dynamic multimedia, but more than that, it is capable of displaying multimedia that is very interactive.
\end{abstract}

Keywords: Swishmax, Employment, Multimedia Learning

Abstrak: Ada beberapa faktor yang mempengaruhi pembelajaran, termasuk faktor guru, faktor siswa, fasilitas, alat dan media, dan lingkungan. Pendidik harus memperhatikan faktor-faktor yang mempengaruhi pembelajaran. Tugas guru dalam proses pembelajaran, selain menyampaikan informasi, juga mendiagnosis kesulitan belajar siswa memilih bahan ajar, mengawasi kegiatan belajar, merangsang kegiatan belajar siswa, memberikan bimbingan belajar menggunakan media, strategi, dan metode. Guru dan siswa dituntut untuk menguasai ilmu komunikasi dan teknologi informasi secara terus menerus. Guru perlu mengikuti perkembangan informasi komunikasi dan sains sehingga mereka dapat menyampaikan materi pembelajaran terbaru yang berguna bagi kehidupan siswa di masa sekarang dan masa depan. Hal yang menonjol dalam Swishmax adalah bahwa karya tersebut dapat diekspor ke format file SWF, yang merupakan format file yang digunakan oleh Macromedia Flash. Oleh karena itu, animasi swishmax dapat diputar di komputer pribadi apa pun yang memiliki flash player yang diinstal. Animasi Swishmax dapat dimasukkan ke halaman web, atau diimpor ke dokumen flash macromedia atau bahkan dalam dokumen Microsoft Power Point. Jika dibandingkan dengan adobe flash, Swishmax lebih mudah dipelajari dan digunakan untuk pemula, karena alat yang tersedia lebih ramah pengguna. Dari uraian di atas dapat disimpulkan bahwa Swishmax bukan hanya perangkat lunak multimedia yang hanya mampu menciptakan multimedia dinamis, tetapi lebih dari itu, ia mampu menampilkan multimedia yang sangat interaktif.

Kata kunci: Swishmax, Ketenagakerjaan, Pembelajaran Multimedia

\section{PENDAHULUAN}

Perkembangan teknologi informasi pada saat ini berkembang dengan pesat. Perkembangan tersebut menuntut guru untuk mampu memanfaatkannya dalam pembelajaran, misalnya untuk membuat media pembelajaran yang interaktif berbasis komputer dan multimedia atau yang dikenal dengan pembelajaran ICT (Information Communication Technology) sehingga guru tidak hanya mengandalkan buku dengan pembelajaran sistem konvensional. Menurut Sidiq dalam Rusman (2012:26) pada dasarnya proses pembelajaran adalah proses komunikasi antara guru dan siswa melalui verbal sebagai media utama penyampaian materi pembelajaran. Guru sebagai perencana pembelajaran yang dituntut mampu merancang pembelajaran dengan memanfaatkan berbagai jenis media dan sumber belajar yang sesuai agar proses pembelajaran berlangsung secara efektif dan efesien.

Terdapat beberapa faktor yang mempengaruhi pembelajaran, diantaranya adalah faktor guru, faktor siswa, sarana, alat dan media, serta lingkungan. Sudah seharusnya pendidik memperhatikan faktor yang mempengaruhi pembelajaran. Menurut Saputro dalam Asyhar (2010:5) tugas guru dalam proses pembelajaran, di samping menyampaikan informasi, juga mendiagnosis kesulitan belajar siswa menyeleksi materi ajar, mensupervisi kegiatan belajar, menstimulus kegiatan belajar siswa, memberikan bimbingan belajar menggunakan media, strategi, dan metode. Pengajar dan peserta didik dituntut untuk menguasai ilmu 
pengetahuan dan teknologi informasi komunikasi secara terus menerus. Pengajar perlu terus mengikuti perkembangan ilmu pengetahuan dan teknologi informasi komunikasi agar dapat menyampaikan materi pembelajaran yang mutakhir dan berguna bagi kehidupan peserta didik dimasa kini dan masa yang akan datang(Munir, 2009:5).

Tidak diragukan lagi bahwa multimedia memiliki peran yang sangat penting dalam mendukung proses pembelajaran. Dari segi penyampaian informasi, multimedia memiliki kemampuan untuk menghadirkan fenomena alam yang tidak mungkin berada dalam kelas. Hal ini tentunya merupakan suatu informasi yang sebelumnya tidak dapat diberikan kepada siswa. Harga perangkat komputer seperti kita ketahui semakin murah dan informasi semakin mudah didapatkan, merupakan angin segar dalam mempercepat kesempatan pada proses pembelajaran berbasis swishmax. Kita dapat menyaksikan sekarang, laptop menjadi barang umum. Pada saat pembelajaran berlangsung, selain membawa beberapa referensi, guru tidak ketinggalan membawa laptop.

Berdasarkan hasil wawancara dan observasi yang dilakukan di kelas XI IPS 4 SMA Negeri 8 Kota Jambi, diperoleh bahwa pemanfaatan infocus dan komputer sebagai multimedia pembelajaran kurang optimal. Karena guru hanya menggunakan media pembelajaran presentasi microsoft power point dalam memberikan materi tertentu saja dan guru masih menggunakan media papan tulis dalam menggambar serta proses pembelajaran yang begitu monoton.

Dengan demikian nilai tersebut merupakan gambaran hasil belajar siswa selama setengah semester mereka mengikuti kegiatan belajar mengajar di sekolah. Dari tabel 1.1 di atas menunjukkan bahwa hasil belajar ekonomi siswa kelas XI IPS 4 SMA Negeri 8 Kota Jambi masih rendah dan perlu diperbaiki supaya hasil belajar ekonomi siswa dapat meningkat.

Menurut Asyhar (2010:32) media pembelajaran dapat membantu pendidik dalam memfasilitasi proses belajar peserta didik. Media pembelajaran juga dapat membantu pendidik untuk mempermudah proses belajar mengajar, memperjelas materi pelajaran dengan beragam contoh yang konkret melalui media, memfasilitasi interaksi dengan pembelajar, dan memberi kesempatan praktik kepada mereka. Sehingga dengan media diharapkan peserta didik lebih berperan aktif dalam proses kegiatan belajar mengajar. Menurut Riyana dalam Asyhar (2010:33) melalui media suatu proses pembelajaran bisa lebih menarik dan menyenangkan, dengan menggunakan media berteknologi seperti halnya komputer, multimedia, internet dan lain-lain sangat membantu peserta didik dalam belajar dan memperkaya pengetahuan. Salah satu media teknologi seperti swishmax mampu memberikan gambaran dan visualisasi materi-materi yang membutuhkan pemahaman visual yang lebih banyak. Animasi akan membangkitkan minat belajar siswa dan dapat meningkatkan hasil belajar siswa.

Hasil penelitian yang pernah dilakukan oleh Safitri, Hartono dan Somakim (2013) peneliti melakukan penelitian dengan judul "Pengembangan Media Pembelajaran Matematika Pokok Bahasan Segitiga Menggunakan Macromedia Flash Untuk Siswa Kelas VII SMP”. Penelitian tersebut menggunakan program macromedia flash, ternyata siswa yang mengikuti pembelajaran dengan menggunakan media pembelajaran pada materi segitiga tersebut memberikan respon positif dan juga media pembelajaran tersebut memiliki efek potensial terhadap hasil belajar siswa sebanyak $85 \%$ siswa dinyatakan tuntas dengan nilai yang telah ditetapkan yaitu di atas 71. Sedangkan Cahya (2012) menggunakan aplikasi macromedia pada pelajaran topologi jaringan komputer berbasis macromedia flash dan menunjukkan hasil belajar siswa yang lebih baik dari pada pembelajaran yang tidak menggunakan aplikasi media pembelajaran topologi jaringan komputer berbasis macromedia flash. Penelitian yang juga dilakukan oleh Lingin (2012) dalam pengembangan media pembelajaran interaktif pada mata pelajaran geografi juga menyebutkan manfaat yang diperoleh dari penggunaan media pembelajaran interaktif adalah konsep yang disajikan mudah dipelajari, dipahami, dan sistematis.

Dari contoh-contoh hasil penelitian yang relevan penggunaan multimedia pembelajaran menunjukkan bahwa penggunaan media pembelajaran dapat meningkatkan hasil belajar siswa dan memberi kesempatan pada peserta didik untuk belajar sesuai dengan kecepatan masing-masing, belajar lebih cepat dan tidak menimbulkan kebosanan karena dilengkapi dengan gambar dan animasi serta soal latihan yang bervariasi. Multimedia pembelajaran interaktif ini juga dapat digunakan sebagai alternatif media pembelajaran secara klasikal maupun individual. Perbedaan hasil belajar geografi antara siswa yang dibelajarkan dengan menggunakan media pembelajaran buku teks seperti yang dilakukan oleh Lingin (2012) 
menunjukkan bahwa multimedia pembelajaran mampu untuk meningkatkan hasil belajar siswa secara signifikan.

Berdasarkan hal di atas, maka dianggap perlu adanya multimedia pembelajaran yang mampu mengajak siswa untuk ikut berpartisipasi dan semangat dalam mengikuti proses pembelajaran, bila perlu multimedia pembelajaran tersebut mampu membuat siswa belajar mandiri jika suatu saat guru tidak dapat mengisi pelajaran di kelas serta efektif dalam meningkatkan hasil belajar siswa. Multimedia dapat digunakan sebagai alternatif di dalam pembelajaran karena efektif dalam meningkatkan proses pembelajaran dan hasil belajar siswa menurut Munadi dalam Rusman (2012:123). Multimedia pembelajaran yang akan dihasilkan oleh penulis memiliki ciri khusus yaitu mudah digunakan, menarik, dan menyenangkan serta materi yang dipaparkan sesuai dengan kompetensi dasar yang telah ditentukan.

Selain hal di atas, alat bantu atau multimedia pembelajaran yang beragam dapat menciptakan variasi dalam proses pembelajaran. Berkaitan dengan dibutuhkannya alat bantu atau media pembelajaran dalam usaha menciptakan proses kegiatan belajar mengajar yang menarik, aktif, inovatif, kreatif, efektif dan menyenangkan. Maka dari itulah penulis melakukan penelitian di bidang pendidikan berupa pengembangan multimedia pembelajaran berbasis swishmax. Dalam pengembangan media pembelajaran saat ini telah banyak software atau program yang dikembangkan sebagai media pembelajaran guna menghantarkan ilmu ekonomi kepada siswa. Program yang dikembangkan ini disesuaikan dengan kebutuhan pembelajaran sehingga mampu memberi stimulus kepada peserta didik dalam mempelajari ekonomi dan diharapkan dapat meningkatkan minat dan motivasi belajar siswa, serta dapat meningkatkan hasil belajar yang dicapai.

Materi ketenagakerjaan memerlukan adanya visualisasi dan animasi untuk membantu menggambarkan materi yang akan disampaikan kepada siswa. Supaya siswa lebih memahami materi ketenagakerjaan dan menimbulkan rasa ingin tahu tentang materi tersebut. Mempelajari materi ketenagakerjaan yang digambarkan di buku teks dan papan tulis seperti yang dilakukan dalam pembelajaran konvensional dapat menimbulkan miskonsepsi pada siswa. Maka dari itu perlu dikembangkan multimedia pembelajaran tentang materi tersebut. Multimedia pembelajaran ini dirancang dengan menggunakan aplikasi swishmax, karena kelebihan swishmax terletak pada kemampuannya menghasilkan animasi gerak dan suara dengan cara yang lebih mudah dibandingkan dengan software animasi lain.

Uraian di atas mendorong penulis untuk mencoba mengembangkan software swishmax menjadi multimedia pembelajaran agar hasil belajar ekonomi siswa bisa mencapai KKM dan siswa bisa dengan mudah memahami pelajaran ekonomi khususnya pada pokok bahasan ketenagakerjaan. Software ini dipilih penulis karena swishmax merupakan software flash yang sangat mudah penggunaannya bagi pemula dibandingkan software lainnya. Software ini memiliki beberapa keunggulan yaitu mampu membuat animasi gambar secara halus dengan warna-warna yang cerah sehingga dapat mempercepat stimulus yang diberikan guru kepada siswa dan memiliki kemampuan untuk membuat pembelajaran lebih interaktif, karena swishmax dilengkapi dengan berbagai macam script yang berisi perintah-perintah dan dapat dijalankan seperti layaknya sebuah software. Oleh sebab itu, berangkat dari permasalahan yang ada maka penulis tertarik untuk mengadakan penelitian dengan judul "Pengembangan Multimedia Pembelajaran Berbasis Lash Animation With Swish Max Materi Bahasan Ketenagakerjaan Siswa Kelas XI SMA Negeri 8 Kota Jambi”.

\section{METODOLOGI PENELITIAN}

Jenis penelitian ini adalah penelitian pengembangan (Research and Development) yaitu penelitian yang digunakan untuk menghasilkan produk tertentu, dan menguji keefektifan produk tersebut (Sugiyono, 2014:407). Sedangkan menurut Borg \& Gall dalam Setyosari (2012:215), penelitian pengembangan adalah suatu proses yang dipakai untuk mengembangkan dan memvalidasi produk pendidikan. Langkah-langkah penelitian atau proses pengembangan ini terdiri dari kajian tentang temuan penelitian produk yang dikembangkan, mengembangkan produk berdasarkan temuan-temuan tersebut, melakukan uji coba produk sesuai latar di mana produk tersebut akan dipakai, melakukan revisi terhadap hasil uji lapangan. Pengembangan yang penulis lakukan dalam penelitian ini adalah pengembangan multimedia pembelajaran berbasis swishmax pada pokok bahasan ketenagakerjaan di kelas XI IPS 1 SMAN 2 Kota Jambi.

Model pengembangan yang digunakan adalah model pengembangan ADDIE yang dikembangkan oleh Lee \& Owens (2004:93). Model pengembangan ini terdiri dari lima tahapan yaitu: (1) analisis 
(Analysis); (2) desain (design); (3) pengembangan (development); (4) implementasi (implementation); dan (5) evaluasi (evaluation). Adapun langkah-langkah pengembangan menurut model Lee \& Owens dapat dilihat di bagan berikut:

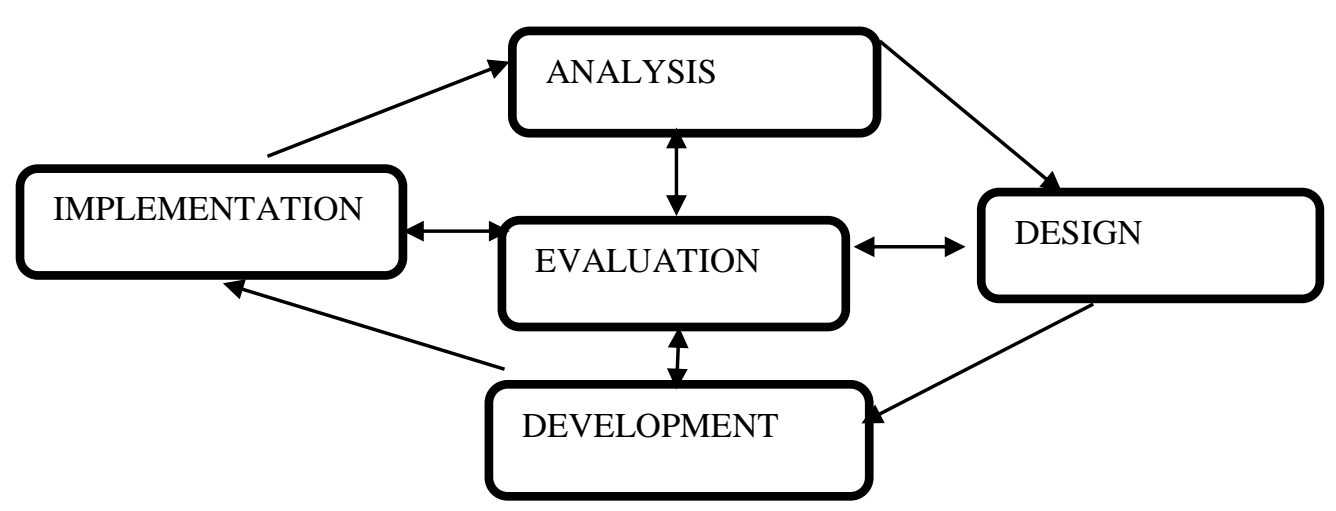

Gambar 1 Bagan Pengembangan Model ADDIE

Alasan dipilihnya model Lee \& Owens dikarenakan (1) model ini termasuk ke dalam model prosedural yang bersifat deskriptif, di susun secara sistematis untuk mencapai tujuan pembelajaran, menunjukkan langkah-langkah yang jelas dan cermat untuk menghasilkan produk, serta (2) tahap-tahap pengembangan dalam model ini sama dengan standar tahap pengembangan, namun model ini dirancang khusus untuk multimedia pembelajaran yang sesuai dengan produk yang dikembangkan.

Adapun desain uji coba ini adalah produk awal yang dibuat oleh peneliti sebelum divalidasi dan diuji coba sehingga belum mengalami revisi. Menurut Jayusman (2015:42) desain uji coba adalah produk yang telah dihasilkan melalui beberapa tahap yang telah dilewati dalam prosedur pengembangan. Desain uji coba ini kemudian diberikan kepada validator yang akan menilai produk yang dibuat dari aspek media dan aspek materi, sehingga akan diketahui kelemahan-kelemahan perangkat multimedia yang telah dibuat. Subjek uji coba dalam penelitian pengembangan ini adalah siswa kelas XI IPS 1 SMAN 2 Kota Jambi. Untuk uji coba kelompok kecil dilakukan kepada 6 orang siswa dan 23 orang siswa untuk uji coba kelompok besar.

Jenis data yang diperoleh dari hasil uji coba pada penelitian pengembangan ini bersifat kuantitatif dan kualitatif. Data kuantitatif diperoleh dari respon siswa mengenai multimedia pembelajaran berbasis swishmax. Sedangkan data kualitatif diperoleh dari hasil validasi ahli media dan ahli materi terhadap multimedia yang telah dikembangkan.

Untuk menghasilkan produk yang berkualitas, sangat diperlukan instrumen yang mampu menggali apa yang dikehendaki dalam pengembangan produk. Instrumen pengumpulan data yang digunakan dalam penelitian pengembangan ini berupa angket. Angket merupakan suatu alat pengumpulan data yang digunakan dengan cara memberikan serangkaian daftar pertanyaan tertulis untuk diisi atau dijawab oleh responden (Hariwijaya dan Triton, 2008:61). Angket digunakan untuk memperoleh data kualitatif dan data kuantitatif.

Adapun angket untuk ahli media terdiri dari 12 deskriptor dengan menggunakan 4 skala jawaban serta kolom saran perbaikan pada setiap pertanyaan. Tabel berikut ini adalah kisi-kisi instrumen angket yang digunakan untuk penilaian produk multimedia pembelajaran yang dikembangkan menurut Yamasari (2010:6) terlihat seperti pada table 1 berikut ini:

Tabel 1 Kisi-Kisi Instrumen Angket Penilaian Oleh Ahli Media

\begin{tabular}{llll}
\hline Variabel & Indikator & Deskriptor & $\begin{array}{l}\text { No. Butir } \\
\text { Instrumen }\end{array}$ \\
\hline $\begin{array}{llll}\text { Penggunaan multimedia pembelajaran } \\
\text { berbasis swishmax pada pokok }\end{array}$ & Kesederhanaan & Sederhana & 1 \\
bahasan Ketenagakerjaan & & Mudah dimengerti & 2 \\
& & Karakteristik siswa & 3 \\
& & Kalimat yang mudah dimengerti & 4 \\
& \multirow{2}{*}{ Keterpaduan } & Urutan setiap halam sesuai & 5 \\
& & Petunjuk/tombol yang digunakan mudah dan jelas & 6 \\
\end{tabular}




$\begin{array}{lll}\text { Penekanan } & \text { Penekanan terhadap materi } & 7 \\ \text { Keseimbangan } & \text { Ukuran tulisan sesuai } & 8 \\ \text { Bentuk } & \text { Media yang digunakan menarik } & 9 \\ & \text { Bentuk huruf mudah dibaca } & 10 \\ \text { Warna } & \text { Warna setiap halaman sesuai } & 11 \\ & \text { Dagrasi warna sesuai } & 12\end{array}$

Sedangkan angket untuk ahli materi terdiri dari 15 deskriptor dengan menggunakan 4 skala jawaban serta kolom saran perbaikan pada setiap pertanyaan. Adapun instrumen penilaian dari ahli materi, kisikisinya menurut Wahono dalam Sari (2013:38), terlihat seperti pada tabel 2 berikut ini:

Tabel 2 Kisi-Kisi Instrumen Angket Penilaian Oleh Ahli Materi.

\begin{tabular}{llll}
\hline Variabel & Indikator & Deskriptor & No. Butir Instrumen \\
\hline Pengembangan & Kriteria & Program mempunyai topik yang jelas & 1 \\
multimedia & Pendidikan & Program sesuai dengan silabus kurikulum & 2 \\
pembelajaran & (Educational & materi sesuai dengan kd, indikator, dan tujuan pembelajaran & 3 \\
berbasis swishmax & Criteria $)$ & Isi materi mempunyai konsep materi yang benar dan tepat & 4 \\
pada pokok & & Program membantu menjelaskan konsep pelajaran & 5 \\
bahasan & Program memiliki soal latihan & 6 \\
ketenagakerjaan & Tampilan program membuat siswa tertarik & 7 \\
& Kesesuaian animasi dengan materi & 8 \\
& Struktur program fleksibel terhadap pengguna & 9 \\
& Tampilan program jelas & 10 \\
& Tampilan program menarik & 11 \\
& Memungkinkan siswa belajar mandiri & 12 \\
& Kecocokan soal dengan latihan materi & 13 \\
& Bahasa yang digunakan mudah dimengerti & 14 \\
\hline
\end{tabular}

Sedangkan angket untuk siswa terdiri dari 12 deskriptor untuk uji coba kelompok kecil dan 16 deskriptor untuk uji coba kelompok besar dengan menggunakan 4 skala jawaban berupa nilai 4 untuk keterangan sangat setuju, nilai 3 untuk keterangan setuju, nilai 2 untuk keterangan tidak setuju nilai 1 untuk keterangan sangat tidak setuju. Adapun angket yang digunakan untuk penilaian oleh siswa menurut Wahono dalam Sari (2013:39), terlihat seperti pada tabel 3 dan 4 berikut ini:

Tabel 3 Kisi-kisi Instrumen Angket Penilaian Siswa Kelompok Kecil

\begin{tabular}{|c|c|c|c|}
\hline Variabel & Indikator & Deskriptor & No Butir Instrumen \\
\hline \multirow[t]{2}{*}{$\begin{array}{l}\text { Pengembangan } \\
\text { multimedia } \\
\text { pembelajaran } \\
\text { berbasis swishmax } \\
\text { pada pokok bahasan } \\
\text { ketenagakerjaan }\end{array}$} & $\begin{array}{l}\text { Efektivitas } \\
\text { media }\end{array}$ & $\begin{array}{l}\text { Dapat digunakan sebagai media pembelajaran ekonomi. } \\
\text { Isi media sudah relevan dengan materi yang dipelajari. } \\
\text { Isi media mudah untuk dimengerti dan dipahami. } \\
\text { Isi media sesuai dengan konsep materi yang dipelajari. } \\
\text { Media dapat digunakan dengan mudah dan fleksibel. } \\
\text { Penggunaan media sebagai media pembelajaran dapat } \\
\text { membantu siswa dalam memperoleh informasi tentang } \\
\text { pembelajaran ekonomi yang dipelajari }\end{array}$ & $1,2,3,4,5,6$ \\
\hline & $\begin{array}{l}\text { Motivasi } \\
\text { belajar }\end{array}$ & $\begin{array}{l}\text { Penggunaan multimedia sebagai media pembelajaran } \\
\text { membuat siswa lebih bersemangat untuk belajar. } \\
\text { Penggunaan multimedia pembelajaran membuat belajar } \\
\text { ekonomi lebih menyenangkan. } \\
\text { Produk multimedia sebagai media pembelajaran membuat } \\
\text { siswa tidak merasa bosan } \\
\text { Produk multimedia sebagai multimedia pembelajaran } \\
\text { membuat siswa lebih tertarik untuk belajar ekonomi. } \\
\text { Produk multimedia sebagai multimedia pembelajaran } \\
\text { merangsang rasa ingin tahu siswa lebih dalam. } \\
\text { Produk multimedia sebagai multimedia pembelajaran } \\
\text { meningkatkan perhatian siswa untuk belajar ekonomi. }\end{array}$ & $7,8,9,10,11,12$ \\
\hline
\end{tabular}


Tabel 4 Kisi-Kisi Instrumen Angket Penilaian Siswa Kelompok Besar

\begin{tabular}{|c|c|c|c|}
\hline Variabel & Indikator & Deskriptor & No Butir Instrumen \\
\hline \multirow{15}{*}{$\begin{array}{l}\text { Pengembangan } \\
\text { multimedia } \\
\text { pembelajaran berbasis } \\
\text { swishmax pada pokok } \\
\text { bahasan } \\
\text { ketenagakerjaan }\end{array}$} & \multirow{6}{*}{$\begin{array}{l}\text { Efektivitas } \\
\text { media }\end{array}$} & Dapat digunakan sebagai media pembelajaran ekonomi. & \multirow[t]{6}{*}{$1,2,3,4,5,6$} \\
\hline & & Isi media sudah relevan dengan materi yang dipelajari. & \\
\hline & & Isi media mudah untuk dimengerti dan dipahami. & \\
\hline & & Isi media sesuai dengan konsep materi yang dipelajari. & \\
\hline & & Media dapat digunakan dengan mudah dan fleksibel. & \\
\hline & & $\begin{array}{l}\text { Penggunaan media sebagai media pembelajaran dapat membantu } \\
\text { siswa dalam memperoleh informasi tentang pembelajaran } \\
\text { ekonomi yang dipelajari. }\end{array}$ & \\
\hline & \multirow[t]{6}{*}{$\begin{array}{l}\text { Motivasi } \\
\text { belajar }\end{array}$} & $\begin{array}{l}\text { Penggunaan multimedia sebagai media pembelajaran membuat } \\
\text { siswa lebih bersemangat untuk belajar. }\end{array}$ & \multirow[t]{6}{*}{$7,8,9,10,11,12$} \\
\hline & & $\begin{array}{l}\text { Penggunaan multimedia pembelajaran membuat belajar } \\
\text { ekonomi lebih menyenangkan. }\end{array}$ & \\
\hline & & $\begin{array}{l}\text { Produk multimedia sebagai media pembelajaran membuat siswa } \\
\text { tidak merasa bosan }\end{array}$ & \\
\hline & & $\begin{array}{l}\text { Produk multimedia sebagai multimedia pembelajaran membuat } \\
\text { siswa lebih tertarik untuk belajar ekonomi. }\end{array}$ & \\
\hline & & $\begin{array}{l}\text { Produk multimedia sebagai multimedia } \\
\text { merangsang rasa ingin tahu siswa lebih dalam. }\end{array}$ & \\
\hline & & $\begin{array}{l}\text { Produk multimedia sebagai multimedia pembelajaran } \\
\text { meningkatkan perhatian siswa untuk belajar ekonomi. }\end{array}$ & \\
\hline & \multirow[t]{3}{*}{$\begin{array}{l}\text { Aktivitas } \\
\text { belajar } \\
\text { siswa }\end{array}$} & $\begin{array}{l}\text { Produk multimedia dapat membuat siswa belajar lebih mandiri. } \\
\text { Produk multimedia pembelajaran dapat meningkatkan partisipasi } \\
\text { siswa dalam pembelajaran ekonomi. }\end{array}$ & \multirow[t]{3}{*}{$13,14,15,16$} \\
\hline & & $\begin{array}{l}\text { Produk multimedia pembelajaran dapat membantu siswa dalam } \\
\text { menyelesaikan persoalan yang muncul dalam pembelajaran } \\
\text { ekonomi. }\end{array}$ & \\
\hline & & $\begin{array}{l}\text { Produk multimedia sebagai media pembelajaran dapat } \\
\text { membantu siswa untuk berpikir kreatif. }\end{array}$ & \\
\hline
\end{tabular}

Pada penelitian ini data yang diperoleh berupa data kualitatif dan data kuantitatif. Data kualitatif diperoleh dari tim validasi yaitu ahli media dan ahli materi mengenai penilaian, komentar dan saran perbaikan untuk produk multimedia yang dikembangkan. Untuk data kuantitatif diperoleh dari penilaian uji coba kelompok kecil dan uji coba kelompok besar terhadap produk multimedia pembelajaran yang akan dianalisis dengan menggunakan Rating Scale. Rating Scale adalah suatu set kategori yang dirancang untuk mendapatkan informasi mengenai sifat-sifat kuantitatif dan kualitatif. Rating Scale dipilih karena lebih fleksibel, tidak terbatas untuk pengukuran sikap saja tetapi untuk mengukur persepsi responden terhadap fenomena lainnya seperti skala untuk mengukur status sosial ekonomi, pengetahuan dan lain-lain. (Sugiyono, 2014:141)

\section{HASIL DAN PEMBAHASAN}

\section{Hasil Analisis}

\section{Analisis kebutuhan siswa dan karakteristik siswa}

Analisis kebutuhan dan karakteristik siswa meliputi tingkat perkembangan kognitif dan latar belakang pengetahuan siswa dalam mengoperasikan komputer, pengetahuan awal siswa tentang pembelajaran ketenagakerjaan. Hasil analisis tersebut akan dijadikan acuan dalam mendesain produk yang dihasilkan. Hasil analisis kebutuhan dan karakteristik siswa yang didapat dari hasil observasi dan wawancara dengan beberapa siswa kelas XI IPS di SMA Negeri 2 Kota Jambi yaitu siswa dapat mengoperasikan komputer dan siswa lebih sering menggunakan laptop atau komputer di rumah dan warnet daripada di sekolah. Selanjutnya materi ketenagakerjaan merupakan salah satu materi yang sulit, hal ini dapat dilihat dari hasil belajar yang rendah, ditambah lagi dengan jarangnya guru menggunakan media dalam pembelajaran dan buku sebagai satu-satunya sumber belajar. Akibatnya siswa mengalami kesulitan dalam memahami pelajaran, sehingga dibutuhkanlah alat bantu dalam proses pembelajaran. 


\section{Analisis tujuan}

Adapun hasil analisis tujuan didapat bahwa tujuan pembelajaran tentang penguasaan kompetensi yang ditargetkan untuk dicapai sesuai kurikulum 2013. Kurikulum 2013 bertujuan untuk mempersiapkan manusia Indonesia agar memiliki kemampuan hidup sebagai pribadi dan warga Negara yang beriman, produktif, kreatif, inovatif dan efektif serta mampu berkontribusi pada kehidupan bermasyarakat, berbangsa, bernegara dan peradaban dunia. Kompetensi Dasar (KD) pada pembelajaran ekonomi dengan kurikulum 2013, yaitu: menyajikan hasil analisis masalah ketenagakerjaan di Indonesia, dan menganalisis permasalahan ketenagakerjaan di Indonesia.

\section{Analisis materi}

Adapun hasil analisis materi diketahui bahwa masih banyak siswa yang kurang tanggap dalam mengingat dan memahami pembelajaran khususnya pada materi ketenagakerjaan yang disampaikan oleh guru. Oleh karena itu dibutuhkan pengembangan multimedia pembelajaran baru yang dapat mengatasi masalah tersebut yaitu dilakukan pengembangan multimedia pembelajaran menggunakan swishmax. Dengan adanya multimedia pembelajaran berbasis swishmax yang dikembangkan oleh peneliti, diharapkan dapat membantu guru dalam proses pembelajaran dan dapat menarik perhatian siswa serta dapat mempermudah siswa dalam memahami materi ketenagakerjaan.

\section{Analisis teknologi pendidikan}

Adapun hasil analisis teknologi pendidikan didapat bahwa di SMA Negeri 2 Kota Jambi telah memiliki sarana dan prasarana di sekolah yang bisa menunjang proses pembelajaran seperti laboratorium komputer, infocus, serta speaker aktif yang dapat dipergunakan dalam proses pembelajaran. Di setiap ruang kelas belum disediakan infocus, akan tetapi pengajar bisa menggunakan infokus yang disediakan oleh sekolah dengan meminjam terlebih dahulu ke petugas IT untuk proses belajar di kelas.

\section{Hasil Desain (design)}

Dalam mendesain multimedia pembelajaran ini, hal yang peneliti lakukan pertama kali adalah membuat flowchart yang akan digunakan pada proses produksi, selanjutnya berdasarkan flowchart tersebut kemudian membuat storyboard sebagai dasar peneliti untuk membuat multimedia pembelajaran. Selanjutnya pengintegrasian semua bahan-bahan dan materi ke dalam scane swishmax berdasarkan storyboard. Adapun hasil desain produk multimedia pembelajaran ketenagakerjaan dapat dilihat di lampiran 2 berupa flowchart dan lampiran 3 berupa stroryboard.

\section{Hasil Pengembangan (development)}

Tahap pengembangan merupakan tahap di mana proses pengembangan multimedia mulai dilakukan. Pada pembuatan multimedia pembelajaran ini menggunakan software swishmax. Dengan software ini, peneliti dapat menggabungkan teks, gambar, animasi, video, dan musik pengiring untuk pembelajaran ketenagakerjaan sesuai dengan yang telah peneliti lakukan. Adapun hasil pengembangan produk multimedia pembelajaran sebagai berikut:

\section{Halaman pembuka}

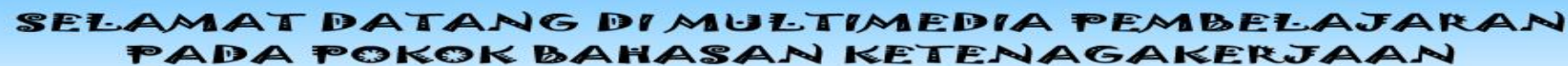

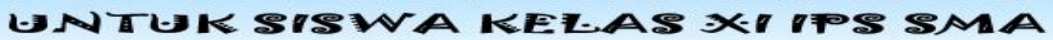
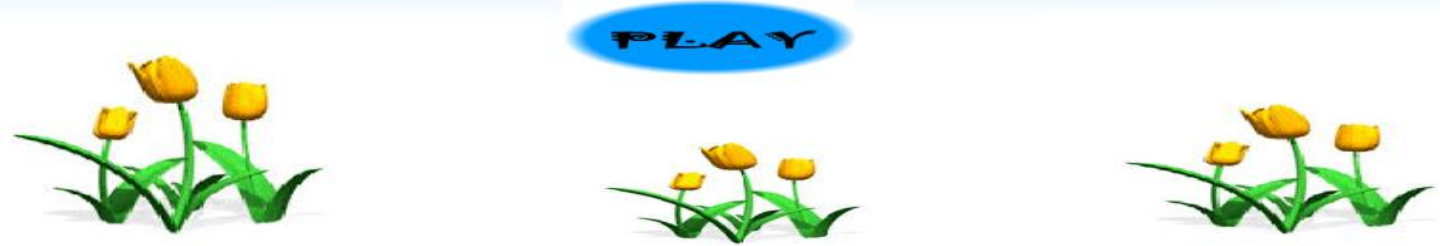

Gambar 2 Halaman Pembuka 


\section{Halaman menu utama}

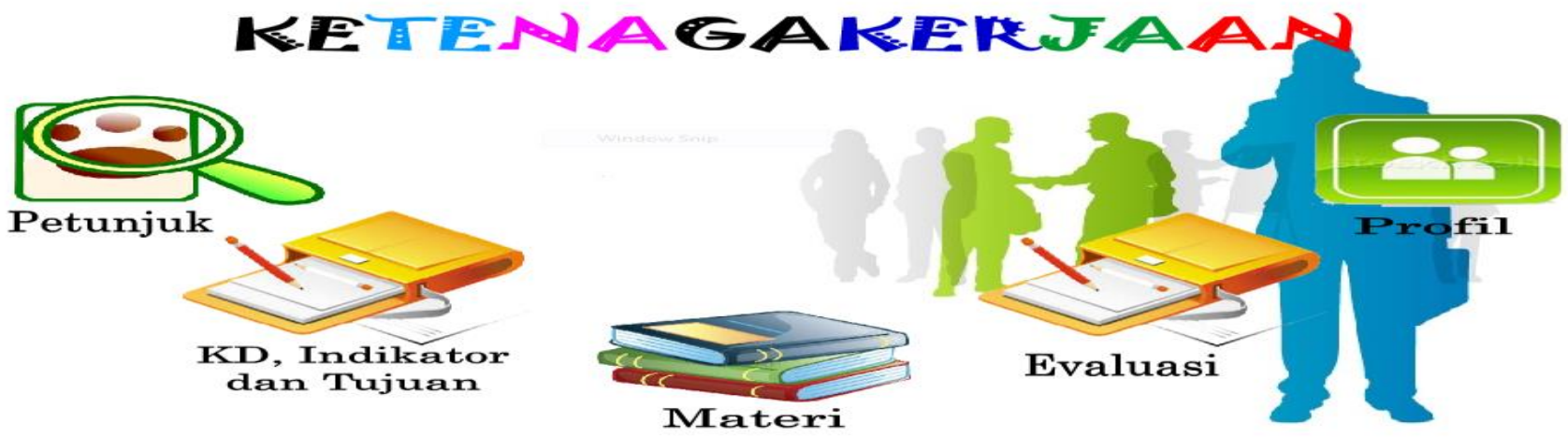

Gambar 3 Halaman Menu Utama

\section{Halaman petunjuk}

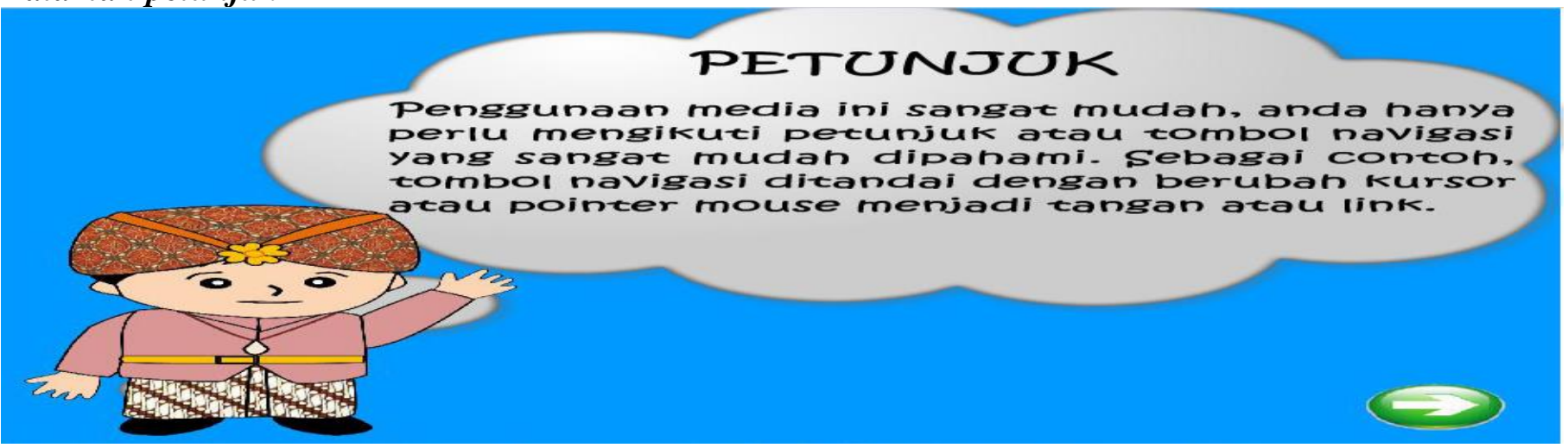

Gambar 4 Halaman Petunjuk

Halaman KD, indikator, dan tujuan pembelajaran

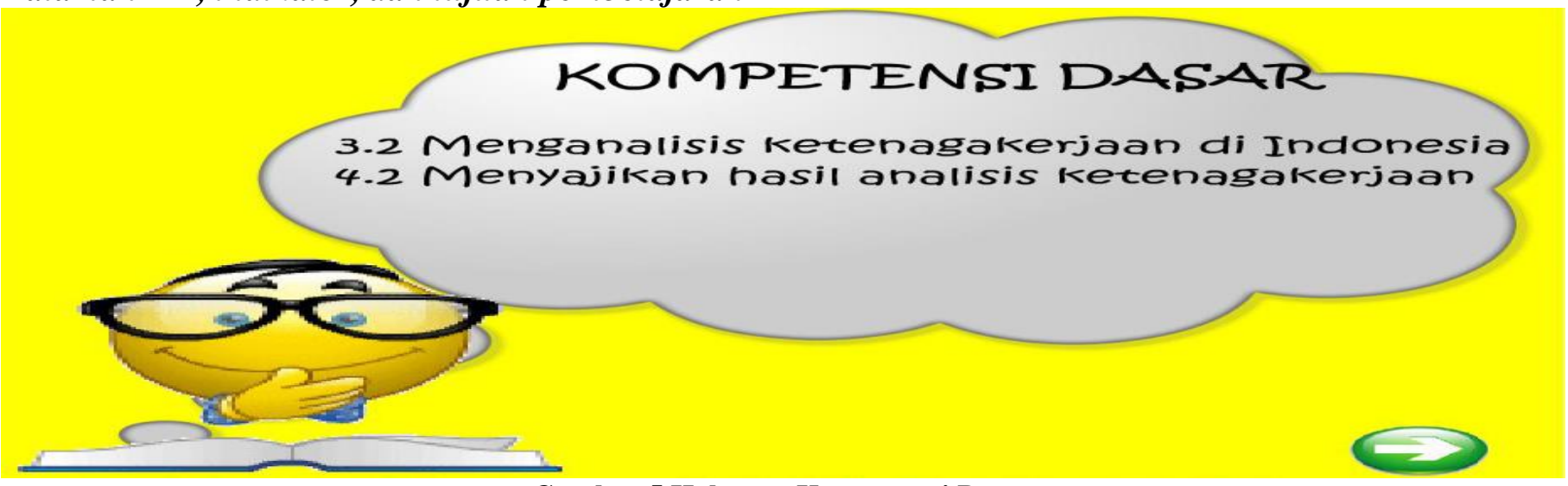

Gambar 5 Halaman Kompetensi Dasar

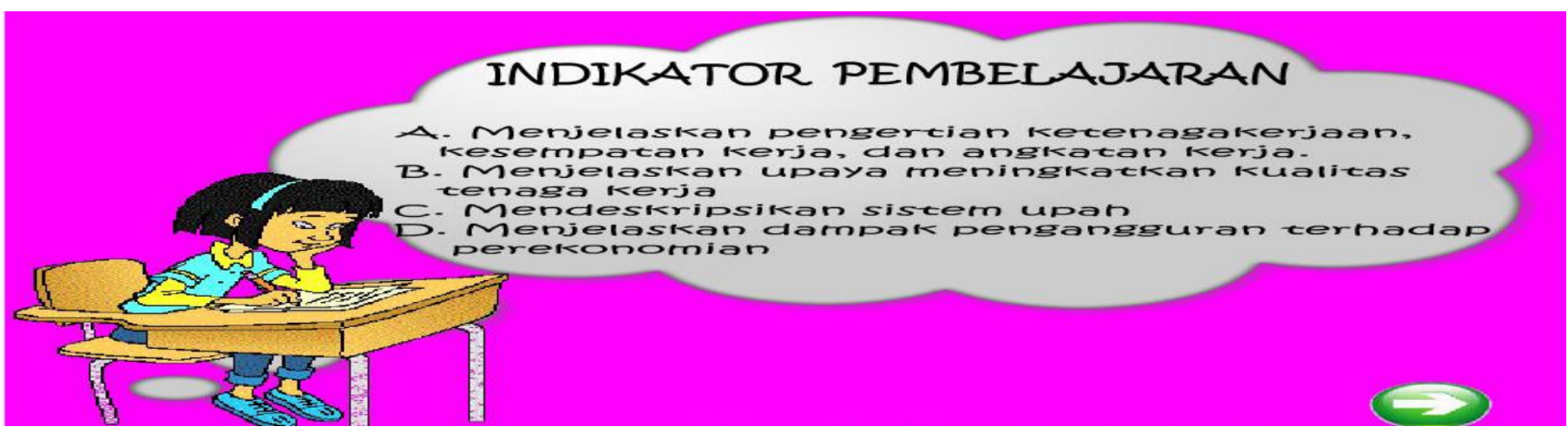

Gambar 6 Halaman Indikator Pembelajaran 


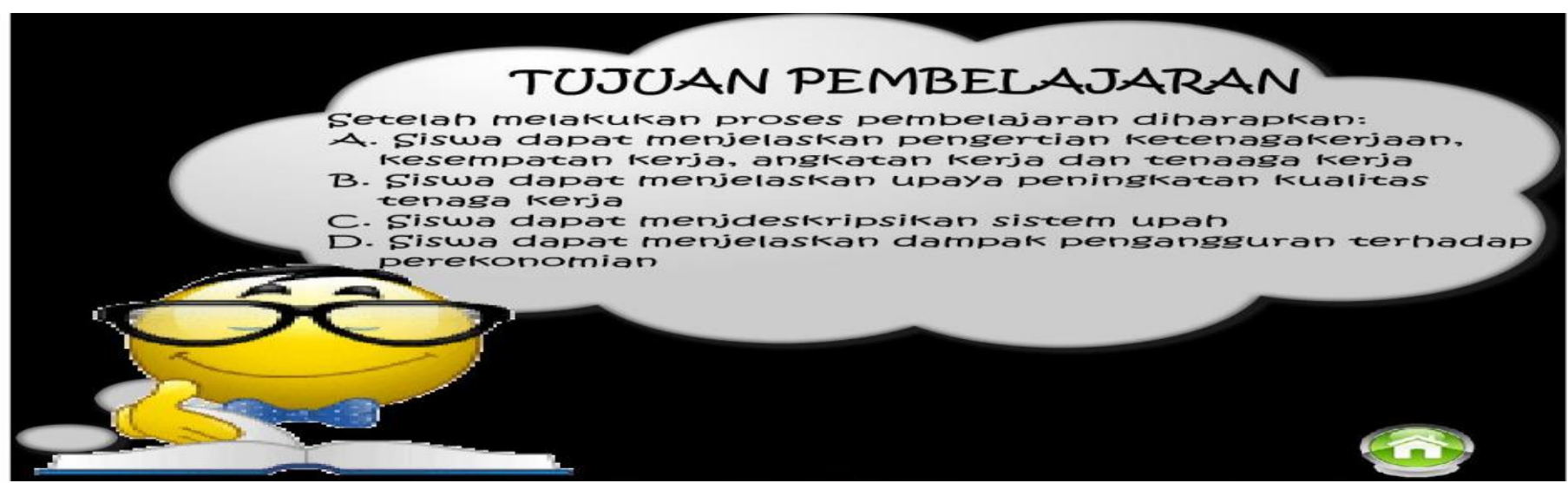

Gambar 7 Halaman Tujuan Pembelajaran

\section{Halaman materi}

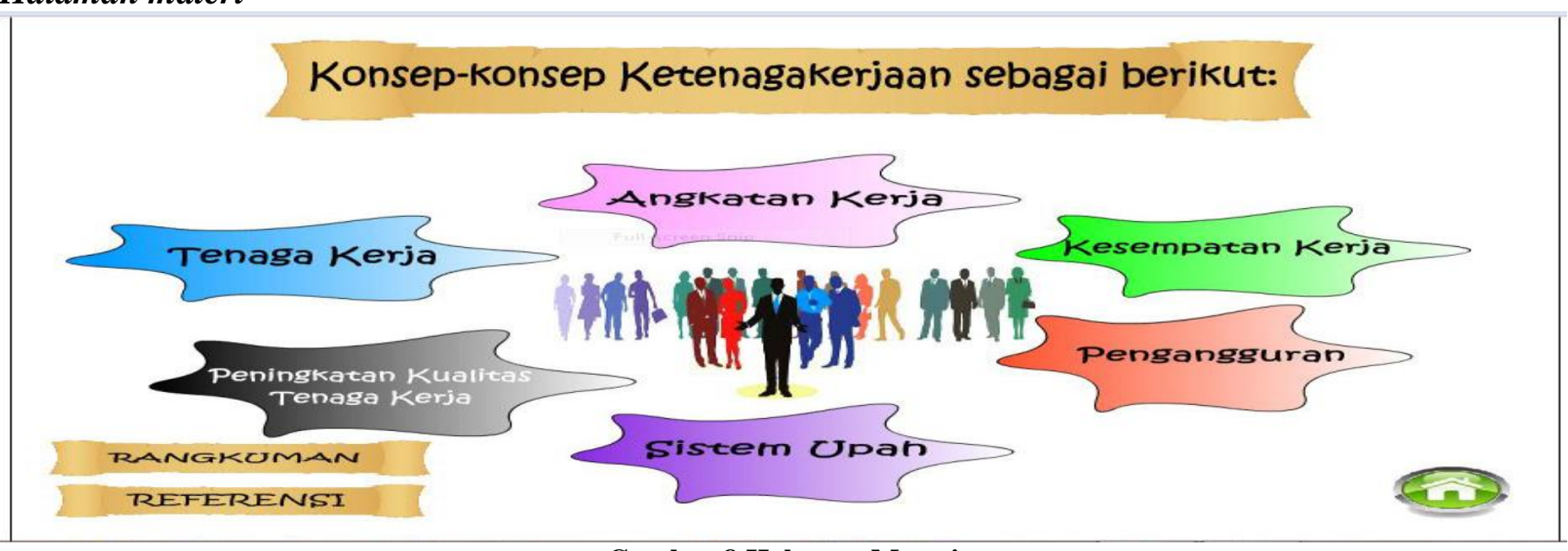

Gambar 8 Halaman Materi

\section{Halaman evaluasi}

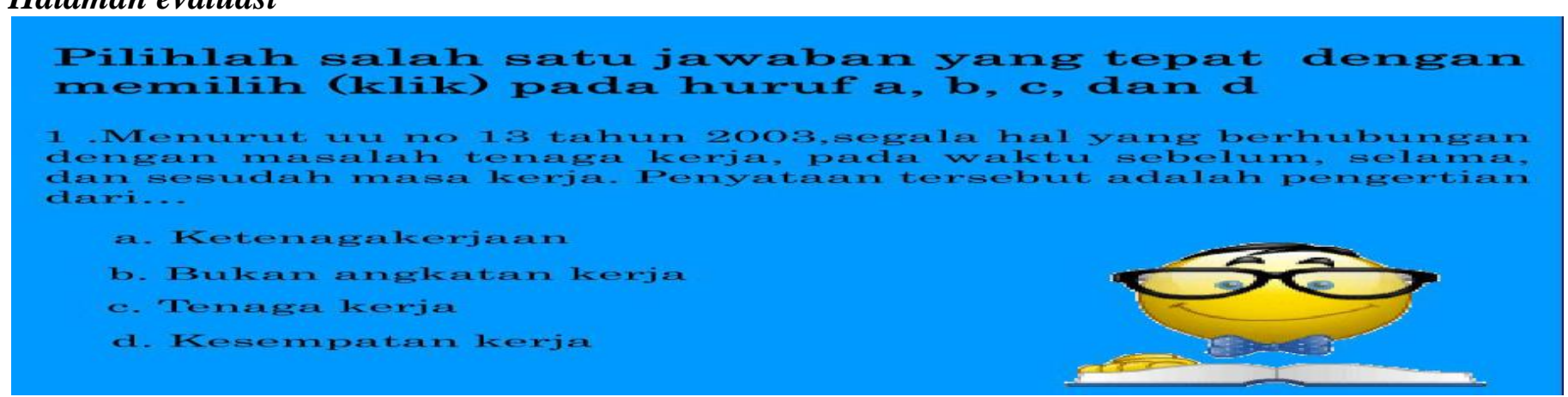

Gambar 9 Halaman Evaluasi

\section{Data Hasil Validasi Ahli Media}

Multimedia pembelajaran yang telah selesai dibuat kemudian divalidasi oleh ahli media yaitu Bapak Drs. Saharudin, M.Ed., M. App., Sc., Ph.D. Validasi media pembelajaran dilakukan untuk menilai kelayakan desain multimedia pembelajaran. Proses validasi ini dilakukan sebanyak 1 kali, dari hasil validasi tersebut terdapat banyak saran dan perbaikan terhadap multimedia yang dikembangkan.

Adapun hasil analisis data pada validasi pertama, ahli media pembelajaran menilai dan memberi saran perbaikan multimedia yang dikembangkan. Angket validasi media terdiri dari 12 pertanyaan yang diisi berdasarkan kriteria yang telah ditentukan (sangat setuju, setuju, tidak setuju dan sangat tidak setuju). Hasil penilaian oleh ahli media kemudian dihitung berdasakan skor yang terdapat di dalam angket tersebut. Analisis perhitungan jumlah skor kriterium (N) yaitu bila skor tertinggi 4 × 12 × $1=48$, di mana $4=$ skor tertinggi tiap butir soal, 12 = jumlah pertanyaan, dan $1=$ jumlah responden. 


\section{Data Hasil Validasi Ahli Materi}

Multimedia pembelajaran yang telah selesai dibuat kemudian divalidasi oleh ahli materi yaitu Bapak Prof. Dr. Drs. H. Khairinal, Dpt. BA., M.Si. Proses Validasi ini dilakukan sebanyak 1 kali.

Dari hasil validasi pada tabel di atas, maka dilakukan analisis data. Adapun hasil analisis data validasi oleh ahli materi pembelajaran menilai dan memberi saran perbaikan multimedia yang dikembangkan. Angket validasi materi terdiri dari 15 pertanyaan yang diisi berdasarkan kriteria yang telah ditentukan (sangat setuju, setuju, tidak setuju dan sangat tidak setuju). Hasil penilaian oleh ahli materi kemudian dihitung berdasakan skor yang terdapat di dalam angket tersebut. Analisis perhitungan jumlah skor kriterium $(\mathrm{N})$ yaitu bila skor tertinggi $4 \times 15 \times 1=60$, di mana $4=$ skor tertinggi tiap butir soal, $15=$ jumlah pertanyaan, dan $1=$ jumlah responden.

\section{Hasil Implementasi (implementation)}

Pada tahap ini, produk yang telah divalidasi oleh tim ahli dan telah direvisi siap untuk diujicobakan kepada siswa. Multimedia pembelajaran berbasis swishmax pada pokok bahasan ketenagakerjaan diimplementasikan dengan uji coba kelompok kecil dan uji coba kelompok besar di kelas XI IPS 1 SMA Negeri 2 Kota Jambi, dengan jumlah responden untuk kelompok kecil sebanyak 6 orang siswa, dan jumlah responden kelompok besar sebanyak 23 orang siswa. Penerapan multimedia pembelajaran ini menggunakan laptop dan infocus sebagai alat bantu, serta penilaian oleh responden melalui angket. Hasil implementasi untuk uji coba terhadap produk multimedia pembelajaran ini dapat dijelaskan sebagai berikut:

\section{Data Hasil Uji Coba Kelompok Kecil}

Uji coba kelompok kecil melibatkan 6 orang siswa untuk mengoperasikan dan menggunakan multimedia pembelajaran yang dikembangkan. Uji coba selanjutnya dilakukan kepada 6 orang siswa yang dipilih secara acak, siswa dibagi menjadi 3 kelompok dan masing-masing beranggotakan 2 orang. Masingmasing kelompok diberi petunjuk penggunaan multimedia dengan tujuan untuk mengetahui dampak penggunaan multimedia pembelajaran terhadap hasil belajar siswa dilakukan pretest dan posttest.

Adapun hasil uji coba pada multimedia pembelajaran berbasis swishmax pada pokok bahasan ketenagakerjaan dijelaskan pada uji coba kelompok kecil dengan jumlah 6 orang siswa dengan perolehan skor 285, skor maksimal adalah 288, maka hasil persentasenya adalah Error! Reference source not found. x $100 \%=98,95 \%$ termasuk dalam kategori "sangat baik". Hal ini menunjukkan bahwa produk multimedia pembelajaran yang telah dikembangkan oleh peneliti layak digunakan dalam proses pembelajaran khususnya pada pokok bahasan ketenagakerjaan.

\section{Data Hasil Uji Coba Kelompok Besar}

Setelah uji coba kelompok kecil dilaksanakan, langkah selanjutnya adalah melakukan uji coba kelompok besar. Uji coba kelompok besar dilakukan kepada siswa kelas XI IPS 1 SMA Negeri 1 Muaro Jambi yang berjumlah 23 orang. Tujuan dilakukannya uji coba kelompok besar ini adalah untuk mengetahui seberapa efektif multimedia digunakan dan melihat kelayakan produk ditinjau dari beberapa aspek. Keefektifan tesebut dilihat berdasarkan perbedaan hasil belajar siswa sebelum dan sesudah menggunakan multimedia dalam proses pembelajaran.

Uji coba diikuti oleh 23 orang siswa dengan berpedoman pada RPP yang telah disusun sebelumnya. Sebelum menggunakan multimedia, peserta didik terlebih dahulu melakukan pretest dan dilanjutkan dengan proses pembelajaran berdasarkan RPP yang telah dipersiapkan sebelumnya. Pada akhir pembelajaran peserta didik diberikan soal posttest untuk mengetahui perbedaan hasil belajar. Setelah itu siswa juga diberikan angket tanggapan terhadap multimedia pembelajaran yang dikembangkan untuk mengetahui kelayakan produk multimedia yang dihasilkan. Kelayakan produk ini diperoleh berdasarkan 3 indikator untuk penilaian yang meliputi keefektifan, motivasi dan aktivitas. Adapun hasil uji coba multimedia pembelajaran berbasis swishmax pada pokok bahasan ketenagakerjaan terdapat pada uji coba kelompok besar dengan jumlah 23 orang siswa dengan perolehan skor 1467, skor maksimal adalah 1472, maka hasil persentasenya adalah Error! Reference source not found. $x 100 \%=99,66 \%$ termasuk dalam kategori "sangat baik". Hal ini menunjukkan bahwa produk multimedia pembelajaran yang telah dikembangkan oleh peneliti layak digunakan dalam proses pembelajaran khususnya pada pokok bahasan ketenagakerjaan. 


\section{Hasil Evaluasi (evaluation)}

Tahap evaluasi merupakan tahap terakhir pada pengembangan multimedia yang dikembangkan. Kegiatan yang dilakukan adalah untuk mengetahui seberapa besar tanggapan pengguna terhadap multimedia yang dikembangkan dan peningkatan pengetahuan siswa. Hasil evaluasi yang diperoleh dari tim ahli yaitu ahli media dan ahli materi menunjukkan bahwa produk multimedia yang dikembangkan dinyatakan sangat baik dan layak digunakan dalam pembelajaran. Selain hasil dari validasi kedua ahli tersebut, hasil evaluasi juga diperoleh berdasarkan hasil uji coba kelompok kecil dan uji coba kelompok besar. Adapun hasil evaluasi pada uji coba kelompok kecil dan kelompok besar dikategorikan sangat baik dan menunjukkan bahwa produk multimedia pembelajaran yang telah dikembangkan oleh peneliti layak digunakan dalam proses pembelajaran khususnya pada pokok bahasan ketenagakerjaan.

Berdasarkan hasil tes yang dilakukan terhadap 23 orang siswa kelas XI IPS 1, dapat diketahui bahwa hasil belajar siswa mengalami peningkatan meski tidak terlalu tinggi persentasenya yaitu $24,26 \%$. Saat dilakukan pretest, dari 23 orang siswa yang mengikuti, hanya 4 orang siswa yang mencapai ketuntasan dan 19 orang siswa tidak mencapai ketuntasan (nilai ketuntasan adalah 76). Pada awal pertemuan dilaksanakan pretest dan setelah itu siswa dibelajarkan dengan menggunakan multimedia pembelajaran. Maka tahap selanjutnya siswa diberi posttest dengan soal yang sama ketika pretest dilaksanakan. Dari hasil posttest yang telah dilaksanakan dapat diketahui bahwa hasil belajar siswa mengalami peningkatan. Hasil posttest menunjukkan bahwa dari 23 orang siswa terdapat 4 orang siswa dinyatakan tidak lulus sedangkan 19 orang siswa dinyatakan lulus. Dengan demikian dapat disimpulkan bahwa multimedia pembelajaran berbasis swishmax pada pokok bahasan ketenagakerjaan yang dikembangkan efektif dalam meningkatkan hasil belajar siswa.

\section{SIMPULAN}

Berdasarkan hasil penelitian pengembangan dan pembahasan terkait multimedia pembelajaran berbasis swishmax pada pokok bahasan ketenagakerjaan yang telah dikembangkan maka ada beberapa hal yang dapat dikaji, yaitu:

1. Penelitian dan pengembangan yang dilakukan menggunakan model ADDIE yang dikembangkan oleh Lee dan Owens melalui beberapa langkah atau tahap yaitu: tahap analisis, tahap desain, tahap pengembangan, tahap implementasi dan terakhir tahap evaluasi yang telah menghasilkan produk multimedia pada pokok bahasan ketenagakerjaan dengan menggunakan software swishmax. Produk ini dilengkapi dengan petunjuk penggunaan, kompetensi dasar, indikator pembelajaran, tujuan pembelajaran, materi, rangkuman, evaluasi dan profil.

2. Penggunaan multimedia sebagai alat bantu dalam pembelajaran memberikan dampak terhadap hasil belajar (pretest dan posttest). Hal ini dibuktikan dengan adanya peningkatan hasil belajar siswa berdasarkan nilai pretest dan posttest uji coba kelompok kecil yaitu sebesar 34,17\% (58,33 menjadi 92,5). Sedangkan untuk peningkatan hasil belajar siswa berdasarkan nilai pretest dan posttest uji coba kelompok besar yaitu 24,26\% (59,69 menjadi 83,95). Berdasarkan dari hasil pretest dan posttest pada uji coba kelompok kecil dan uji coba kelompok besar dapat disimpulkan bahwa produk multimedia pembelajaran yang telah dikembangkan oleh peneliti efektif dalam meningkatkan hasil belajar siswa khususnya pada pokok bahasan ketenagakerjaan.

\section{DAFTAR PUSTAKA}

Alam, S. 2015. Buku Ekonomi SMA/MA Kelas XI Kurikulum 2013. Jakarta:Esis. Ariani, N., Haryanto, D. 2010. Pembelajaran Multimedia Di Sekolah. Jakarta: Prestasi Pustaka Publisher. Arsyad, Azhar. 2013. Media Pembelajaran. Jakarta: Raja Grafindo Persada. Asyhar, Rayandra. 2010. Kreatif Mengembangkan Media Pembelajaran. Jakarta: Gaung Persada Press. Cahya, Indra Bisono. 2012. Penggunaan Aplikasi Multimedia Pembelajaran Topologi Jaringan Komputer Berbasis Macromedia Flash Untuk Meningkatkan Hasil Belajar Mata Pelajaran TIK Siswa SMA N 1 Godean, Yogyakarta. Jurnal. Universitas Negeri Yogyakarta.

Hariwijaya, M., Triton, P. B. 2008. Pedoman Penulisan Ilmiah Proposal Dan Skripsi. Yogyakarta:Oryza. 
Jayusman, Septian Ari. 2015. Pengembangan Media Pembelajaran Matematika Berbasis Geogebra Pada Materi Persamaan Garis Lurus Di Kelas VIII SMP Negeri 8 Kota Jambi. Jurnal. Jambi: Universitas Jambi.

Lingin. 2012. Pengembangan Media Pembelajaran Interaktif Pada Mata Pelajaran Geografi. Jurnal. Medan: Program Pasca Sarjana UNIMED.

Mulyatiningsih, Endang. 2012. Metode Penelitian Terapan Bidang Pendidikan. Bandung: Alfabeta.

Munir. 2009. Pembelajaran Jarak Jauh Berbasis Teknologi Informasi dan Komunikasi. Bandung: Alfabeta. Undang-Undang Nomor 13 Tahun 2003

Putri, L. N., Amira, Z., dan Riani, A. A. 2014. Pengembangan Media Pembelajaran Interaktif Dengan Aplikasi Swishmax Pada Materi Perbaikan Perangakat Pheriperal Komputer Di Kelas XI SMK. Jurnal. Padang: Universitas Bung Hatta.

Rusman. 2012. Belajar dan Pembelajaran Berbasis Komputer: Mengembangkan Profesional Guru Abad 21. Bandung: Alfabeta.

Safitri, M, Hartono, Y., dan Somakim. 2013. Pengembangan Media Pembelajaran Matematika Pokok Bahasan Segitiga Menggunakan Macromedia Flash Untuk Siswa Kelas VII SMP. Jurnal. Palembang: Universitas Sriwijaya.

Sari, Pebri. 2013. Pengembangan Media Pembelajaran Fisika SMP Kelas VIII Berbasis Website Menggunakan Microsoft Frontpage Pada Materi Tekanan. Jurnal. Jambi: Universitas Jambi.

Sarwiko. D. 2011. Pengembangan Media Pembelajaran Berbasis Multimedia Interaktif Menggunakan Macromedia Director MX. Jurnal Sistem Informasi. Depok: Universitas Gunadarma.

Setyosari, Punaji. 2012. Metode Penelitian Pendidikan Dan Pengembangan. Jakarta: Kencana Prenada Media Group.

Sugiyono. 2014. Metode Penelitian Kuantitatif Kualitatfif dan R\&D. Bandung: Alfabeta.

Syah, Muhibbin. 2003. Psikologi Belajar. Jakarta: Raja Grarapindo Persada.

Syarif, Arry Maulana. 2005. Cara Cepat Membuat Animasi Flash Menggunakan Swishmax. Yogyakarta: Penerbit ANDI.

Warsita, Bambang. 2008. Teknologi Pendidikan: Landasan dan Aplikasinya. Jakarta: Rineka Cipta.

Widiastuti, Anik. 2013. Problematika Ketenagakerjaan Di Indonesia. Diktat. Yogyakarta:Universitas Negeri Yogyakarta.

Wisah, A. R., Gunawan, H. 2010. Belajar Animasi Swishmax 2.0. Palembang: Palcomteh Publisher.

Zahroh, S. H., Widjianto., dan Sumarjono. 2013. Pengembangan Media Pembelajaran Fisika Berbasis Animasi Swishmax Disertai Scaffolding Untuk Membantu Belajar Mandiri dan Memahami Konsep Fluida Satatis. Jurnal. Malang: Universitas Negeri Malang.

Yamasari, Y. 2010. Pengembangan Media Pembelajaran Matematika Berbasis ICT yang Berkualitas. Jurnal. Surabaya: Program Pasca Sarjana Institut Teknologi Sepuluh November. 